\title{
The Role of Children's Age and Gender, and Friends' Gender in the Children's Interaction towards Social Problem Solving Strategies in Preschool Children
}

\author{
Rita Eka Irzaty ${ }^{1}$ \\ ${ }^{1}$ Department of Psychology, Universitas Negeri Yogyakarta, \\ Jl. Colombo No. Depok, Sleman, Yogyakarta 55281, Indonesia \\ rita_ekaizzaty@uny.ac.id
}

\begin{abstract}
Social problem-solving strategy accepted by society is the essential accomplishments in the development of pre-school children. However, until recent studies, social problem-solving strategies among pre-school children in Indonesia is still rarely conducted. This research examines the role of age, gender in children, and friends' gender towards social problem-solving strategies. This research utilised a purposive sampling that voluntarily involved 162 children 4-6 years old. Those children were selected from an intact family consisting of a father, mother and children who lived together. A hypothetical social situation dilemma was utilised to gather social problemsolving strategies data from the subjects. The data were analysed with the use of cross-tabulation and chi-square test. Concerning the data analysis, the results reveal no significant difference in social problem-solving strategies when viewed in terms of age and gender of the children and friends' gender. This suggests that children ages 4 to 6 years for boys and girls still have the same patterns of social behaviour dealing with similar gender and different ones.
\end{abstract}

Keywords: social problem-solving strategy; gender; children's interaction

\section{Introduction}

Social competence has been an exciting topic among parents, educators, and school psychologists across the nation. Researchers and psychologists commonly use social competence to help explain why some children succeed while others fail in their peer interactions. It is believed that through cooperative interactions in the years from pre-school through early elementary school, children learn how to take turns, share resources, form and maintain positive peer relationships, and manage conflict (Parker, Rubin, Price, \& DeRosier, 1995). A lack of skill in these areas may be detrimental to a child's social and emotional development. The Preschool period is the stage when group games and continuous interaction with children's peer start. In this period, children can sometimes have conflicts with each other even if they are intimate friends
(Dereli-Iman, 2013). Furthermore, mastering how to handle conflict is essential for their social development because these early relationships are the foundation for future relationships. Thus, peer relation researchers have highlighted the importance of identifying the competencies associated with successful peer interactions in early childhood (Mize \& Cox, 1990).

One definition of social competence is the ability to balance one's own needs in social situations while maintaining positive relationships with others (Rose-Krasnor, 1997). However, exactly how socially competent children master this balance is unclear. The balance between self and relationship goals is difficult to achieve when children's needs conflict with one another (Putallaz, 1983). Although historically, researchers have treated positive and negative behaviours, 
cognitions, and emotions as opposite ends of one continuum, other researchers have proposed that these processes might be independent (Cillessen, 2011; Rodkin \& Hodges, 2003). If this is true, socially competent children may display a mixture of prosocial and antisocial behaviours in conflict situations instead of either one exclusively (Green \& Rechis, 2006)

In Indonesia, social behaviour has been taught since children were 4-6 years old through Kindergarten (TK). This is the implementation of Law No. 20/2003 National Education System Chapter 1, Article 1, and item 14. The behavioural indicator shows children's social competence is the children's ability to share with others, apologising, and solving problems when facing conflict. It is expected that children will interact with peers and adults within socially acceptable behaviour (National Education Department, 2007).

Related to socially accepted behaviour, Social Problem Solving Strategies (from now on referred to as SPSS) is part of social behaviour that becomes an essential antecedent for peer acceptance (Walker, 2004). In this case, SPSS is defined as a strategy used by children in dealing with problems arising from the children's conflict (Berk, 2008; Green \& Rechis, 2006). Shantz (1987) claims that conflict occurs if there is a conflict of interest and the discrepancy between children's need and reality. For children, conflict often occurs because of the intention to use limited objects or friends' interference. Strategies used when resolving conflict issues result from an integration of children's cognitive, emotional, and social aspects development (Berk, 2012). However, the strategies used by children in solving social problems when they experience conflict must be either prosocial or antisocial (Dereli-Iman, 2013).

Previous research showed that a prosocial SPSS provides an effective solution while maintaining a good relationship with peer correlated with peer acceptance in sociometric assessment. On the other hand, agonistic or forceful behaviour tend to hurt others negatively correlated with peer acceptance (Mize \& Ladd, 1988; Musun-Miller, 1993). Aggressive children or likely to harm others is about $40 \%$ to $50 \%$ of the group of rejected children (Rubin, Coplan, Chen, Burkirk, Woljslawawics, 2005).

On the other hand, when facing problems in the social context, children who use passive strategies such as anxious, fearful and withdrawn tend to be reported as rejected. The group with these characters are $10 \%-20 \%$ in a group of low peer acceptance. It is explained further that the relation between withdrawn attitude and low peer acceptance is getting stronger when children move to the end of childhood and early adolescence (Rubin et al., 2005). Rubin's research agreed by Asendorpf, Denissen and Aken (2008) show that 19-year longitudinal research on pre-school children is likely to be aggressive and withdrawn in solving their social problems. Apparently, at the age of 23, they still possess these attitudes.

Izzaty's observation (2009) on 131 children aged 4-6 (79 boys and 53 girls) in 45 Kindergartens in Yogyakarta showed ten types of SPSS occurrence when children face conflict. These SPSS types were grouped into three main categories: aggressive tendency, passive and prosocial behaviours. The results show that aggressive tendencies, including physical/verbal aggression, forceful, destroy things occur $50 \%$, passive (crying, complaining, withdrawing and being silent) is $48 \%$ and has only $2 \%$ prosocial, which showed by intervening, peaceful and asking for permission. This finding encourages this research to discover more about the antecedent and consequences of particular SPSS in children, which is assumed to affect self-development.

From the above literature, it can be concluded that SPSS affects individual 
adaptive functions (Chang, D'zurilla, \& Sanna, 2004) from pre-school to adolescence (Laundry, Smith, \& Swank, 2009) and even in early adulthood (Asendorf, Denissen, \& Aken, 2008). Therefore, children need to be taught and familiarised with acceptable social strategies on a daily basis. Some advantages for children with socially acceptable SPSS are that they will have many friends, fight rarely, work in a group more effectively (Crick \& Dodge, 1994), and face a responsively social situation (Stormshak \& Welsch, 2006). On the contrary, there is a relation among socially unaccepted SPSS and poor academic achievement, mental disorder, delinquency (Parker, Rubin, Price, \& DeRosier, 1995), and various psychopathology forms in the next level of development (Asendorf, Denissen, \& Aken 2008; Mayeux \& Cillessen, 2003).

This study will examine whether age and gender different SPSS scores. Compared to younger children, various literature described elder children using a prosocial SPSS more than passive or coercive SPSS. Elder children have developed more social cognitive, which raise more effective strategies. It can be concluded that the solution to social problem develops gradually. In pre-school children, if it comes to read social cues, they tend to make a simple solution to satisfy themselves, not others-such a condition to a cognitive characteristic of pre-school children who are likely to be egocentric. However, by the time they experience more social diversity, they will learn to persuade and compromise and adapt for the sake of all parties involved. As for gender, previous studies showed that boys tend to use physical aggression SPSS while girls tend to use verbal aggressiveness SPSS. Besides, girls tend to use prosocial SPSS more than boys do.

In addition to age and gender, the role of interacting with friends' gender will also be examined further to see the differences in social problem-solving strategies used by children. Rubin and RoseKrasnor (1993) state that the effect of boys' domination toward girls is the cause of why girl tend to behave prosocially to boys than to other girls. Green, Cillessen, Rechis, Patterson, and Hughes (2008) proved that girls tend to be prosocial to other girls than deal with boys. The research on the influence of interact friends' gender on SPSS in children can describe how gender affects children's perception of solving conflict. Understanding the perception of children 4-6 years old will help the learning program, or the intervention aimed to improve children social skills.

Based on the research framework, there are two proposed hypotheses:1) There are differences in social problemsolving strategies viewed from age and gender, and 2) differences in social problem solving strategies when children deal with a similar and different gender.

\section{Methods}

This research employed a purposive sampling technique to gain the data. These children are from intact family consist of a father, mother and children and living together. The subject of this study were 162 subjects (70 girls and 92 boys), and 212 children 4-6 year old who studied in kindergartens. The study conducted in 6 Kindergarten in Yogyakarta. 5 Kindergartens are in the Sleman Regency and a kindergarten in Yogyakarta city.

To collect the data, this research employed SPSS Instrument. It contains a hypothetical social situation dilemma. There were six social situations presented three situations concern with limited resources such as books, stationery and toys. Three other situations were joining into a group, maintaining position with friends' disturbance, and self-defence against the provocation of mockery. SPSS measuring tools consisted of four parts, two parts for girls interact with girls and boys, and two others were are for boys who 
interact with the same and opposite gender. To validate the result of this measurement, a pilot test was employed. The result of the pilot test is considered valid it brings up answers in the form of SPSS with various categories of $90.4 \%$ of the total responses, while only $9.26 \%$ did not meet the objective response measured.

Meanwhile, to gain the reliability of this research, inter-rater reliability was employed. The average inter-correlation ratio results in all combination made $\left(\bar{r}_{\mathrm{xx}}\right)$ of 0.95 to 1 . At the same time, the reliability of the average made by raters is $\left(\boldsymbol{r}_{\mathrm{xx}}\right.$ ") $)$ of 0.99 to 1.

\section{Findings and Discussion}

1. Hypothesis 1. There are differences in social problem-solving strategies based on children age and gender.

Descriptive statistical analysis of SPSS variables shows that subject on each category is not balanced. Subjects in the prosocial category are $47.5 \%$, passive is $33.3 \%$, and coercive much is $19.1 \%$. The analysis shows no difference in SPSS based on the age and gender of the child. It means that 4 to 6 -year-old children, both boys and girls, do not significantly differ SPSS in response to various conflict situations presented in the measuring instrument. The results of the cross-tabulation show that a comparison of the number of SPSS is used for children 4-5-year-old children and 5-6 year old above. For prosocial strategies, 5-6-year-old use it more than 4-5 year old.

For passive strategy, 4-5-year-old use it more than 5-6 year old, while children over the age of 5 years old respond with coercive strategies more than 4-5 year old. These differences are then tested using the chi-square test to see if the difference in age between SPSS is significant or not. The chisquare test results with a value of $\chi^{2}=1.074$ and $p=0.585 \quad(p>005)$ show no significant difference in SPSS viewed from age. Although there is no difference in the number of prosocial and coercive categories, the chi-square test results show that $\chi^{2}=1.686$ with a probability of significance of 0430 ( $p>0.05$ ) no significant difference in the SPSS when from the gender has.

2. Hypothesis 2. There are differences in social problem-solving strategies when dealing with similar the opposite gender.

From the results of crosstabulation, it is known that in girls, 28 children consistently used a prosocial SPSS either when dealing with friends of the same or different gender, 15 children consistently use passive strategies, and seven children consistently use coercive strategies. Meanwhile, 35 of the 44 children consistently use prosocial strategies for the boys, 26 children consistently use passive strategies, and 21 children use coercive strategies when dealing with friends of the same or different gender.

Furthermore, from the chi-square test results, it is found that both girls and boys are proved to have no significant role that interacts with friends' gender on social problem-solving strategies. Chi-square test results show the value of $\chi^{2}=42.065$ with a significance level of $p<0.05$. It means a significant correlation between girls using SPSS when dealing with similar gender or the opposite gender. This result is also seen in young boys with the value $\chi^{2}=39.548$ with a significance level of $p<0.005$. It can be concluded that are both girls and boys use the same strategy when dealing with friends of the same and different genders.

\section{Discussion}

This research shows that prosocial strategies are the most widely used by children, with 47,5\% occurrences. Meanwhile, passive strategy places on the second rank with 33,3\% occurrences and coercive strategies is in the third rank with $19.1 \%$ occurrences.

Based on these results, it can be concluded that although children cognition 
is in the age of 4 to 6 year old. They know what to do when facing various social dilemma situations, but it does not always indicate that the children will display similar behaviour to what they think of. Based on studies conducted by Choi (2000), one of the reasons the SPSS in pre-school children revealed by interviews and observation producing different values is the lack of training to practice social strategies in various conflict situations. Whereas, according to Piaget, the fact that children experience conflict plays a vital role in the development of children (Dereli-Iman, 2013). Furthermore, from the development of children 4 to 6-year-old, the discrepancy between thought and behaviour does not mean that something has gone wrong. However, it shows the development process, which is relatively unstable (Santrock, 2007). It shows that age was not related to social problem-solving competence in preschooler (Walker \& Henderson, 2012).

Along with age development, there will be suitability between the understanding and the action. Therefore, children need to do repetitive exercises to refine positive behaviour to be internalised in children. This is confirmed by Mills and Rubin (1998) research which shows statement which shows that children 4 to 6 year-old still have the same patterns of social behaviour. In terms of Child Development Psychology, children 4-6 years old are still in the same stage of development. Development tasks on the social aspect of this period are directed to children to learn different kinds of rules beyond their family rules. Parental direction and parental scaffolding can predict children's social competence (Wieland, Green, Ellinsen, \& Baker, 2014). At the end of this period, the children are expected to give and accept something, behave empathically, adequately express themselves, and listen when others are speaking (Berns, 2007; Berk, 2012).
For the role of gender differences in children, this research shows differences from some research. Dodge, Coie, and Lyanam (2006) stated that boys are more physically aggressive than girls, especially when provoked. While Eisenberg, Fabes, and Spinrad (2006) suggests that girls are more prosocial than boys. In line with the second hypothesis, the research also shows that friends interact gender does not significantly contribute to the differences in children SPSS used. The results of this study diversify some previous research results. Research conducted by RoseKrasnor and Rubin (1983) find out that girls tend to use prosocial SPSS to boys compared to other girls because of the dominance effects. As with the research conducted by Green et al. (2008) and research by Parker and Asher (1993), girls tend to bring out the prosocial SPSS to girls than to boys.

There are two statements to explain why the children gender and friends interact gender do not significantly contribute to SPSS differences:

a. First, It may be caused by the absence of parenting differences for boys and girls. Mothers who do not differentiate the rearing between boys and girls become a model for children to respond to gender differences (Hastings, Mcshane, Parker, \& Ladha, 2007). Although since the age of 3 until the end of early childhood (Hartup, 2002), children interact more with similar gender. Children's learning experiences from their mother do not cause them to act socially differently based on gender.

b. Secondly, based on the researcher's observations and interviews with educators and principals on the site, the learning activities program in Kindergartens facilitate both boys and girls to play and learn in a group. Educational training can influence children's SPSS (Malik, Balda, Punia \& 
Duhan, 2010). Experiences at home and school mutually reinforce and stimulate children to explore and try different things without any gender differences. There is continuity between what is taught and socialised at home and at school, which establishes assertive behaviour in children. Greater communication between home and school was related to levels of children behaviour (McComick, Capella, O'Connor, \& Mc Clowry, 2013). Cooperation between parents and the school that affect children's development can also be used to illustrate how the mesosystem layers based on ecological theory affect children's development.

\section{Conclusion}

Age and gender do not influence the children's strategy to solve their social problems. Theoretically, this research supports several earlier research, which revealed that 4 to 6-year-old children still have the same social behaviours. Besides, there is no difference in the children's strategy to solve social problems when interacting with friends who have the same or different gender. It is explained by the possibility that maternal behaviour methods on 4 to 6-year-old children do not differentiate gender. The learning programs in kindergartens did not distinguish the rearing and activities for boys and girls.

\section{Recommendations}

1. For parents and teachers

a. Based on the fact that 4 to 6 years old children's seems to have no correspondence on the strategy they thought and the implementation when faced with social problems, and that they have average acceptance towards their peers, children should be trained continuously to practice various social skills. Johnson, Ironsmith, Snow, dan
Poteat (2000) said that several skills support the development of prosocial behaviour and peers' acceptance, which should be trained on pre-school children by suitable methods-for instance, sharing and helping each other, taking turns to use toys, listening when other people speak, expressing their want or feelings in proper language and cooperative having selfcontrol, and repressing coercive behaviour. Orobio de Castro, Verman, Koops, Bosch, and Monshouwer (2005) and Rubin et al. (2005) added that pre-school children should also be trained to control emotions and empathetic. Furthermore, before or after the skills were introduced and trained, children should understand the meaning and importance of the social skills and friends by showing several examples. When the children show positive behaviours, parents and teachers should encourage affective and rewarding statements. Teaching and reinforcing positive social skills and utilising collaborative and cooperative learning can also promote prosocial behaviour displays (Wentzel \& Brophy, 2014). Habitual and consistent training will encourage strong prosocial behaviour. Teachers can create an emotionally supportive classroom environment at the preschool level through a positive relationship with their students and promote positive interactions among students themselves (Wentzel, 2015).

b. Intervening children who tend to have a passive or coercive strategy is essential. Every time children show passive or coercive strategy, parents and teachers should ask why they do such things. From their answers, parents and teachers can understand the situation and the way children think about it. Passive children should be encouraged to participate in activities that need cooperation and express their 
thoughts and feelings. Giving examples of making a good strategy in various conflicts/situations and explaining the benefits they would get will encourage pre-school children to try. Conflicts enable them to understand that others have different viewpoints, thoughts, feelings, motives and needs (DereliIman, 2013). Besides support and reward from parents and teachers, peers' role is also essential to help children accomplish the skills needed for interacting with friends. Coercive children should be given examples on the proper behaviour in conflict situations. For instance, when a child snatches his or her friend's toy, parents and teacher should ask him or her to imitate verbal expression, such as "I want to play with that toy, could you please lend it to me now?" In conducting the behaviour, parents and teachers would have to make sure that they imitate it properly. Besides giving a direct example, parents and teachers can make a mutual agreement, such as giving a certain amount of time to use toys, crayons, or books. As a result, the child can take turns with his or her friends. Finally, school-initiated parent involvement programs should highlight practices that can promote prosocial behaviour at home, including the use of inductive reasoning and parental modelling positive social interactions (Wentzel, 2015).

2. For further research

Evaluate the influence of the children who tend to have a coercive strategy towards children who tend to have passive SPSS. The alternative theoretical perspective that can be used is the Theory of Social Learning from Albert Bandura. According to Dereli (2009), with this theory, it can be learned how the imitation and observation of the social behaviour between children could influence or change the children's earlier strategy. Further,
Dereli also said that peers are effective models for children, so it has a strong influence in shaping other children's behaviour.

\section{References}

Asendorpf, J. B., Denissen, J. J. A., \& van Aken, M. A. G. (2008). Inhibited and aggressive pre-school children at 23 years of age: Personality and social transitions into adulthood. Developmental Psychology, 44, 997-1011.

Berk, L. E. (2008). Infants and children: Prenatal through middle childhood. Boston, MA: Pearson Education, Inc.

Berk, L. E. (2012). Development through lifespan: Dari prenatal sampai remaja (edisi kelima). Yogyakarta: Pustaka Pelajar.

Berns, R. M. (2007). Child, family, school, community; Socialisation and support. Belmont, CA: Wadsworth Thomson Learning.

Chang, E.C., D'zurilla, T. J., \& Sanna, L.J. (2004). Social problem solving; Theory, research, and training. Washington DC: American Psychological Association.

Choi, D. H. (2000). Changes of pre-school children's social strategy (cognition) and social behaviors after participating in a cognitive-social learning. Proceedings of the Lilian Katz Symposium. Diunduh dari bttp:/ / ericeece.org/pubs

/books/katzsym/choi.pdf/tanggal 22 Oktober 2012.

Cilessen, A. H. N., \& Bellmore, A. D. (2011). Social skills and social competence in interactions with peers. In Peter K. Smith \& Craig Hart. The wiley-blackwell bandbook of social childhood development, second edition. Malden, MA: Blackwell Publishing Ltd. 
Crick, N. R., \& Dodge, K. A. (1994). A review and reformulation of social information-processing mechanisms in children's social adjustment. Psychological Bulletin, 115, 74-101.

Departemen Pendidikan Nasional. (2007). Kompetensi aspek perkembangan anak usia 3-4 dan 5-6 tabun. Jakarta: Depdiknas.

Dereli, E. (2009). Examining the permanence of the effect of a social skills training program for the acquisition of social problem solving skills. Social Behavior and Personality, 37(10), 1419-1428.

Dereli-Iman, E. (2013). Adaptation of Social Problem Solving for Children Questionnaire in 6 Age Groups and its Relationships with Preschool Behavior Problems. Educational Sciences: Theory \& Practice. 13(1) pp. 491-498.

Dodge, K., Coie, J., \& Lynam, D. (2006). Aggression and antisocial behavior in youth. In W. Damon \& R. Lerner (Series Eds.) \& N. Eisenberg (Vol. Ed.), Handbook of child psychology: Vol. 3. Social, emotional, and personality development (6th ed., pp.719-788). New York: Wiley.

Eisenberg, N., Fabes, R A, \& Spinrad, T L. (2006). Prosocial development. In W. Damon (ed): Handbook of child psychology, volume 3: Social, emotional, and personality development. 5th edition. New York: Wiley.

Green, V. A., \& Rechis, R. (2006). Children's cooperative and competitive interactions in limited resource situations: A literature review. Journal of Applied Developmental Psychology, 27, 42-59.

Green, V. A., Cillessen, A. H. N., Rechis, R., Patterson, M. M., \& Hughes, J. M. (2008). Social problem solving and strategy use in young children. The
Journal of Genetic Psychology, 169(1), 92112.

Hartup, W. W. (1992). Peer relations in early and middle childhood. In V. B. Van Hasselt \& M. Hersen (Eds.), Handbook of social development: A lifespan perspective (pp. 257-281). New York, NY: Plenum Press.

Hastings, P. D., McShane, K. E., Parker, R., \& Ladha, F. (2007). Ready to make nice : Parental socialisation of young sons and daughter's prosocial behaviors with peers. The Journal of Genetic Psychology, 162(2), 177-200.

Izzaty, R. E. (2009). Strategi Pemecahan Masalah Sosial pada Anak Taman Kanak-kanak. Laporan Penelitian. Yogyakarta: Universitas Negeri Yogyakarta.

Johnson, C., Ironsmith, M., Snow., C. W., \& Poteat, G. M. (2000). Peer acceptance and social adjustment in pre-school and kindergarten. Early Childhood Education Journal. 27(4), $207-$ 212.

Laundry, S. H., Smith, K. E., \& Swank, P. R. (2009). New directions in evaluating social problem solving in childhood : Early precussors and links to adolescent social competence. New directions in Child and Adolescent Development, 123, 51-68.

Malik, S., Balda, S., Punia, S., \& Duhan, K.(2010). Educating Aberrant Children for Social Problem-Solving. International Journal of Educational Sciences, Vol 2(2): 75-79.

Mayeux, L., \& Cillessen, A. H. N. (2003). Development of social problem solving in early childhood: Stability, change, and associations with social competence. The Journal of Genetic Psychology, 164, 153-173.

McCormick, M. P., Capella, E., O'Connor, E. E., \&McClowry, S. G. (2013). Parent involvement, emotional 
support, and behavior problems: an ecological approach. Chicago Journal Vol. 144, No. 2 pp. 277-300.

Mize, J., \& Cox, R. A. (1990). Social knowledge and social competence: Number and quality of strategies as predictors of peer behavior. The Journal of Genetic Psychology, 151, 117127.

Musun-Miller, 1. (1993). Social acceptance and social problem solving in preschool children. Journal of Applied Developmental Psychology, 14, 59 - 70.

Orobio de Castro, B., Veerman, J. W., Koops, W., Bosch, J. D., \& Monshouwer, H. J. (2002). Hostile attribution of intent and aggressive behavior: A meta-analysis. Child Development, 73(3), 916-934.

Parker, J. G., \& Asher, S. R. (1993). Friendship and friendship quality in middle childhood: Links with peer group acceptance and feelings of loneliness and social dissatisfaction. Developmental Psychology, 29, 611-621.

Parker, J. G., Rubin, K. H., Price, J. M., \& DeRosier, M. E. (1995). Peer relationships, child development, and adjustment: A developmental psychopathology perspective. In D. Cicchetti \& D. J. Cohen (Eds.), Developmental psychopathology: Risk, disorder and adaptation (pp. 96-161). New York, NY: Wiley.

Putallaz, M. (1983). Predicting children's sociometric status from their behavior. Child Development, 54, 14171426.

Rodkin, P.C., \& Hodges, E. V. E. (2003). Bullies and Victims in the Peer Ecology: Four Questions for Psychologists and School Professionals. School Psychology Review, 32(3), 384-400.

Rose-Krasnor, L.,\& Rubin, K. H. (1983). Preschool social problem solving:
Attempts and outcomes in naturalistic interaction. Child Development, 54, 1545-1558.

Rose-Krasnor, L. (1997). The nature of social competence: A theoretical review. Social Development, 6, 111-135.

Rubin, K. H., \& Rose-Krasnor, L. (1992). Interpersonal problem solving and children's social competence. In Van Hasselt, V. B ., Hersen, M. Handbook Of Social Development : A Lifespan Perspective. New York: Plenum Press.

Rubin, K. H., Coplan, R., Chen, X., \& Buskirk, A. A., \& Wojslawowicz, J. C. (2005). Peer relationship in childhood. Diunduh dari http://wwm.rubinlab.umd.edu/pubs/Aks es tanggal 27 Juni 2010.

Santrock, J. W. (2007). Perkembangan anak (ed. 2). Jakarta: Penerbit Erlangga.

Stormshak, E. A., \& Welsh, J. A. (2005). Social competence : A developmental framework. In Teti, D. M. I. Handbook of Research Methods in Developmental Science. Carlton, Victoria: Blackwell Publishing.

Walker, S. (2004). Teacher reports of social behaviour and peer acceptance in early childhood: Sex and social status differences. Child Study Journal, 34(1), 13-28.

Walker, O. L., \& Handerson, H. A. (2012). Temperament and Social Problem Solving Competence in Preschool: Influences on Academic Skills in Early Elementary School. Social Development. Vol. 21 (4) pp. 761-779.

Wentzel, Kathryn. (2015). Prosocial behavior and schooling. Encyclopedia on Early Childhood Development. Departmen of Human Development and Quantitative Methodology, University of Maryland USA. 
Wantzel, K.R., \& Brophy, J. (2014). Motivating Students to Learn. 4th ed. New York, Ny: Taylor Francis.

Wieland, N., Green, S., Ellingsen, R., \& Baker, B. L. (2014). Parent-child problem solving in families of children with or without intellectual disability. Journal of Intellectual Disability Research. Vol 58 (1) pp17-30. 